Reviu Akuntansi dan Bisnis Indonesia, Vol. 1 No. 1, Hlm: 1-14, Juli 2017

Website: http://journal.umy.ac.id/index.php/rab

\title{
Pengaruh Faktor Internal dan Eksternal Auditor Terhadap Perilaku Penghentian Prematur Atas Prosedur Audit: Studi Empiris pada Kantor Akuntan Publik di Yogyakarta dan Semarang
}

Attalia Citra Damayanti; Erni Suryandari Fatmaningrum

Program Studi Akuntansi Univeritas Muhammadiyah Yogyakarta

I N F O A R T I K E L

\section{Kata Kunci:}

Tekanan Waktu, Risiko

Audit, Materialitas,

Prosedur Review dan

Kontrol Kualitas, Locus of

Control Eksternal,

Komitmen Organisasi,

Keinginan untuk Berhenti

Bekerja.

Jenis Artikel:

Penelitian Empiris

Correspondence:

attaliacitra7@gmail.com

\begin{abstract}
A B S T R A K
Penelitian ini bertujuan untuk menguji secara empiris pengaruh faktor internal auditor (komitmen organisasi, locus of control eksternal dan keinginan untuk berhenti bekerja) dan faktor eksternal auditor (tekanan waktu, risiko audit, materialitas, prosedur review dan kontrol kualitas) terhadap perilaku penghentian prematur atas prosedur audit. Data yang dianalisis pada penelitian ini merupakan data primer yang berasal dari jawaban responden terhadap pertanyaan dalam kuesioner. Penelitian ini menggunakan sampel yaitu auditor yang bekerja pada Kantor Akuntan Publik di Yogyakarta dan Semarang. Sampel yang diperoleh dalam penelitian ini berjumlah 45 responden yang dipilih dengan menggunakan metode purposive sampling. Alat analisis yang digunakan adalah SPSS versi 16.0. Metode analisis yang digunakan untuk menguji hipotesis yaitu uji Friedman (Hipotesis 1) dan uji regresi linear berganda (Hipotesis 2-8). Berdasarkan hasil analisis Friedman diketahui bahwa terdapat perbedaan urutan prioritas dari prosedur audit yang dihentikan secara prematur. Berdasarkan hasil analisis regersi linear berganda dapat diketahui bawa tekanan waktu dan locus of control eksternal berpengaruh positif terhadap penghentian prematur atas prosedur audit. Variabel independen lainnya yaitu komitmen organisasi, keinginan untuk berhenti bekerja, risiko audit, materialitas, dan prosedur review \& kontrol kualitas tidak berpengaruh terhadap penghentian prematur atas prosedur audit.
\end{abstract}

(C) 2019 RAB. Published by Universitas Muhammadiyah Yogyakarta

\section{PENDAHULUAN}

Berdasarkan Transparency International Indonesia (TII), indeks persepsi korupsi indonesia (IPK) pada 2016 semakin baik dengan naik satu poin sebesar 37/100, akan tetapi secara global posisi Indonesia masih berada diurutan ke 90 dari 176 negara yang diukur (Ismoyo, 2017). Indonesia berada pada peringkat 13 untuk negara terkorup dari 30 negara se-Asia Pasifik, sedangkan pada tingkat ASEAN, Indonesia berada pada peringkat 7 dari 10 negara yang dilakukan survei (Dharmasaputra, 2017). Rendahnya peringkat di atas, mencerminkan ketidakmaksimalan tanggungjawab akuntan juga aparat hukum dalam mencegah serta menyingkap kasus korupsi di Indonesia (Fakrullah, 2011). Lemahnya audit di Indonesia merupakan permasalahan yang dapat memengaruhi peringkat korupsi tersebut. Salah satu kelemahan audit di Indonesia adalah belum 
adanya undang-undang korupsi tentang suap antar swasta, karena sekarang banyak swasta juga yang sudah menjalankan fungsi publik sebenarnya (Ismoyo, 2017).

Sekretaris Jendral TII menilai bahwa kenaikan IPK pada tahun 2017 menandakan masih berlangsungnya tren positif pemberantasan korupsi di Indonesia, Akan tetapi peningkatan masih cenderung lambat (Putra, 2017). Hal ini terjadi karena pemberantasan korupsi hanya fokus pada sektor birokrasi, sedangkan sektor swasta seperti sektor bisnis belum maksimal (Putra, 2017). Berdasarkan Undang-Undang Republik Indonesia Nomor 5 tahun 2011 yang memuat Peraturan Menteri Keuangan Nomor 17/PMK.01/2008 jasa yang diberikan oleh Kantor Akuntan Publik secara umum ada dua jenis, yaitu jasa atestasi dan jasa non-atestasi. Jasa atestasi merupakan jasa assurance dimana akuntan publik memberikan jasa penjamin dengan menerbitkan suatu laporan tertulis yang menyatakan tentang keandalan pernyataan tertulis yang dibuat oleh pihak lain. Jasa non-atestasi adalah jasa yang diberikan oleh akuntan publik yang di dalamnya tidak memberikan suatu pendapat, tingkat keyakinan, ringkasan temuan, atau bentuk keyakinan.

Akuntan publik sebagai penyedia jasa atestasi memiliki peran yang penting dalam pemberantasan korupsi disektor swasta. Tindakan korupsi dapat diketahui dari hasil audit yang dilakukan oleh akuntan sebagai auditor keuangan. Kasus korupsi dapat terungkap berdasarkan laporan akuntan akan adanya penyimpangan dari laporan keuangan yang mengindikasikan adanya kerugian. Mengungkap kasus korupsi diperlukan hasil audit yang berkualitas, sehingga laporan keuangan dapat dipercaya oleh pihak yang berkepentingan sebagai bahan untuk menentukan langkah selanjutnya (Koesman, 2011). Kualitas audit dapat tercermin ketika akuntan dapat menemukan kecurangan atau pelanggaran yang terjadi beserta bukti-bukti audit yang mendukung sehingga temuan tersebut dapat dipercaya. Auditor harus melaksanakan prosedur audit sebagaimana diatur dalam standar akuntansi yang berlaku untuk memperoleh bukti kompeten yang cukup (Herningsih, 2001).

Namun dalam situasi tertentu seperti adanya time pressure auditor dapat menghentikan satu hingga beberapa prosedur audit (pengentian prematur atas prosedur audit) karena kepribadian yang buruk pada auditor. Faktor lain yang menyebabkan auditor melakukan premature sign off yaitu, seperti pandangan bahwa prosedur audit tersebut tidak penting, kekurangan waktu dalam melakukan proses audit, prosedur tidak material, kurang memahami prosedur, kejenuhan auditor terhadap prosedur audit, dan waktu penyampaian laporan audit yang semakun dekat (Alderman \& Deitrick, 1982; Raghunathan, 1991).

\section{TINJAUAN LITERATUR DAN PERUMUSAN HIPOTESIS}

\section{Teori Atribusi}

Suartana (2010) menyatakan bahwa atribusi adalah proses memelajari bagaimana seseorang menyikapi suatu peristiwa dan menjelaskan penyebab atas perilakunya. Teori atribusi adalah teori yang digagas oleh Heider (1958) dimana tingkah lalu seseorang dipengaruhi antara kekuatan internal yaitu faktor-faktor yang berasal dari dalam diri individu, seperti usaha atau kemampuan, serta kekuatan eksternal, yaitu faktor-faktor yang berasal dari lingkungan seperti keberuntungan atau kesulitan dalam pekerjaan (Suartana, 2010).

Teori atribusi dalam penelitian mengenai keperilakuan, diaplikasikan dengan menggunakan variabel lokus kendali (locus of control). Variabel lokus kendali dibagi menjadi 2 jenis, yaitu lokus kendali internal dan lokus kendali eksternal (Suartana, 2010). Teori X dan Y menyatakan bahwa individu dengan lokus kendali eksternal adalah individu X karena mereka tidak bertanggung jawab, memerlukan motivasi dari lingkungannya serta perlu ada paksaan atau imbalan seperti bonus agar berprestasi. Individu dengan lokus kendali internal adalah individu Y karena mereka suka berusaha, kreatif, bertanggungwajab, serta mampu memotivasi dirinya (McGregor, 1960).

Teori atribusi dapat digunakan untuk mendukung penelitian ini karena dalam penelitian ini akan diuji mengenai variabel-variabel yang dapat mempengaruhi ketepatan pemberian opini auditor yaitu skeptisme profesional yang merupakan kekuatan internal seorang auditor dan independensi 
sebagai faktor yang dapat dipengaruhi oleh pihak luar. Berdasarkan penjelasan di atas maka faktorfaktor yang memengaruhi perlaku individu dalam melakukan penyimpangan dapat dideteksi melalui identifikasi jenis lokus kendali pada auditor, sehingga perilaku prematur sign off dapat diminimalisir.

\section{Perbedaan Urutan Prioritas dari Prosedur Audit yang Dihentikan}

Penelitian yang dilakukan oleh Widyowati (2013) menghasilkan bahwa prosedur yang berpotensi untuk diabaikan adalah prosedur menggunakan pertimbangan auditor internal, sedangkan prosedur yang paling jarang dihentikan adalah prosedur pemahaman bisnis klien. Pertimbangan auditor internal dipilih karena auditor internal merupakan pihak dari perusahaan yang cenderung berkomitmen terhadap keberlangsungan perusahaan sehingga ada kecenderungan untuk memanipulasi pendapatnya jika terdapat hal yang mengancam keberlangsungan perusahaan seperti adanya penyimpangan. Pemahaman bisnis klien dianggap paling penting karena memudahkan auditor dalam mengungkap penyimpangan atau kejanggalan dalam perusahaan. Hal itu karena ia paham bagaimana cara kerja bisnis sehingga apabila terdapat penyimpangan ia dapat berfikir dari sudut pandang pelaku penyimpangan.

Penelitian Wibowo dan Mu'id (2008); Lestari (2010); Nisa (2013) dan Rochman, Andini, dan Oemar (2016) menyimpulkan jika ditemukan perbedaan urutan prioritas prosedur audit yang dihentikan secara prematur. Auditor akan melakukan praktik prematur sign-off terhadap prosedur audit yang paling tidak berisiko diantara sepuluh prosedur audit yang sering diabaikan oleh auditor (Lestari, 2010).

Pemilihan tersebut dipengaruhi oleh kemampuan auditor mengestimasikan risiko yang akan diterima apabila meninggalkan prosedur tertentu. Karena risiko bersifat estimasi, tentu hasil perkiraan tidak selalu sama sehingga menimbulkan perbedaan dalam memilih prosedur yang mungkin dihentikan. Berdasarkan uraian di atas, maka hipotesis pertama dirumuskan sebagai berikut :

$\boldsymbol{H}_{\mathbf{1}}$ : Terdapat perbedaan urutan prioritas dari prosedur audit yang dihentikan secara prematur.

\section{Pengaruh Time Pressure terhadap Perilaku Premature Sign-Off}

Time pressure bagi auditor bertujuan untuk efisiensi biaya audit (Wibowo \& Mu'id, 2008). Semakin cepat waktu yang dibutuhkan untuk mengaudit, maka semakin kecil biaya pelaksanaan audit. Time pressure, mengharuskan auditor supaya dapat menyelesaikan proses audit berdasarkan waktu yang ditentukan. Tuntutan untuk menyelesaikan audit sesuai waktu yang ditetapkan, dapat menyebabkan auditor melakukan penyimpangan audit seperti premature sign off.

Penelitian Lestari (2010) menyimpulkan jika tekanan waktu menunjukkan pengaruh yang positif terhadap premature sign off. Begitu juga dengan penelitian Nisa (2013); Sunyoto (2014); Priyanto (2014); Asrini, Sujana, dan Darmawan (2014); Andani dan Mertha (2014) dan Rochman, et al. (2016) Hal tersebut berarti, semakin tinggi time pressure semakin besar kemungkinan auditor untuk melakukan premature sign-off. Penelitian tersebut menjelaskan, jika auditor merasa khawatir tidak dapat menyelesaikan proses audit tepat pada waktunya, dapat memaksa auditor untuk menghentikan prosedur audit tertentu karena kekurangan waktu audit. Berdasarkan uraian di atas, maka hipotesis kedua dirumuskan sebagai berikut:

$\mathrm{H}_{2} \quad$ : Time Pressure berpengaruh positif terhadap penghentian prematur atas prosedur audit. 


\section{Pengaruh Risiko Audit terhadap Perilaku Premature Sign-Off}

Risiko audit dan bukti audit memiliki hubungan berlawanan (Mulyadi, 2010). Semakin rendah risiko audit maka tingkat kepastian yang diinginkan auditor adalah tinggi sehingga auditor perlu mengumpulkan bukti audit kompeten yang banyak untuk mendeteksi adanya salah saji yang material dan begitu pula sebaliknya. Supaya bahan bukti kompeten yang terkumpul dirasa cukup banyak dan lengkap untuk mendeteksi salah saji material, maka auditor perlu melakukan prosedur yang lebih banyak pula tanpa meninggalkan satu prosedur pun, ketika auditor mengharapkan risiko audit yang rendah, maka auditor harus lebih banyak melakukan prosedur audit sehingga kemungkinan melakukan penghentian prematur atas prosedur audit akan semakin rendah.

Penelitian Lestari (2010) menunjukkan bahwa risko audit berpengaruh positif signifikan terhadap penghentian prematur atas prosedur audit. Begitu pula dengan penelitian Liantih (2010); Qurrahman, Susfayetti, dan Mirandah (2012); Nisa (2013); Budiman (2013); Andani \& Mertha (2014) dan Putriana, Respati, dan Chairina (2015). Semakin besar risiko audit semakin tinggi kemungkinan auditor melakukan penghentian prematur atas prosedur audit. Penelitian tersebut menunjukkan bahwa auditor yang melakukan premature sign-off, cenderung menilai bahwa terdapat risiko audit yang besar pada prosedur audit yang tidak dilaksanakan.

Penelitian di atas menjelaskan bahwa risiko audit yang besar mencerminkan auditor tidak mengumpulkan bukti audit secara luas, artinya auditor tidak melakukan prosedur secara lengkap sesuai standar yang berlaku. Hal tersebut karena keyakinan yang tinggi bahwa, tanpa melaksanakan prosedur audit tersebut, bukti yang ada dirasa cukup untuk memberikan opini audit dengan tepat. Berdasarkan uraian di atas, maka hipotesis ketiga dirumuskan sebagai berikut:

\section{$\boldsymbol{H}_{3} \quad$ : Risiko audit berpengaruh positif terhadap penghentian prematur atas prosedur audit.}

\section{Pengaruh Materialitas terhadap Perilaku Premature Sign-Off}

Pertimbangan auditor mengenai materialitas bersifat estimasi. Penentuan tingkat materialitas dipengaruhi oleh pertimbangan profesional seorang auditor (Mulyadi, 2010). Ketika prosedur audit dianggap memiliki materialitas yang rendah oleh auditor maka semakin tinggi potensi penghentian prematur terhadap prosedur tersebut. Penghentian tersebut dilakukan atas dasar keyakinan bahwa apabila ditemukan salah saji maka nilainya tidak material dan tidak akan mempengaruhi opini audit yang ditetapkan oleh auditor. Lestari (2010) menyimpulkan jika auditor menyatakan tingkat materialitas sebuah prosedur rendah dalam fungsi pendeteksian adanya salah saji, maka semakin besar kemungkinan auditor untuk menghentikan prosedur audit tersebut dan begitu pula sebaliknya semakin tinggi tingkat materialitas prosedur, maka semakin kecil kemungkinan auditior untuk melakukan premature sign off.

Pernyataan di atas sejalan dengan penelitian Wahyudi, Lucyanda, dan Suhud (2011); Asrini, et al. (2014); Haryanto (2015); Junaidi (2016) dan Rochman, et al. (2016), dimana materialitas berpengaruh negatif terhadap penghentian prematur atas prosedur audit. Semakin material suatu informasi akuntansi yang diperoleh melalui prosedur audit tertentu maka semakin penting informasi tersebut sebagai bahan pengambilan keputusan oleh pihak yang berkepentingan. Hal tersebut berarti semakin penting informasi yang ditemukan saat prosedur tertentu, semakin rendah kemungkinan auditor untuk menghilangkan prosedur tersebut atau dengan kata lain material berpengaruh negatif terhadap penghentian prematur. Berdasarkan uraian di atas, maka hipotesis keempat dirumuskan sebagai berikut:

$\boldsymbol{H}_{4}$ : Materialitas berpengaruh negatif terhadap penghentian prematur atas prosedur audit. 


\section{Pengaruh Prosedur Review dan Kontrol Kualitas terhadap Perilaku Premature Sign-Off}

Prosedur review diterapkan untuk mencegah terjadinya premature sign off oleh auditor (Waggoner \& Cashell, 1991). Kebijakan merupakan alat untuk mengontrol segala aktivitas dalam KAP (Messier, 2000). Sistem kontrol kualitas yang baik dapat berfungsi sebagai alat untuk mengontrol penerapan standar profesional oleh auditor. Pelaksanaan prosedur review dan kontrol kualitas yang baik akan memberikan kemudahan dalam mendeteksi disfungsional audit, seperti premature sign off. Kemudahan pendeteksian ini akan mencegah auditor untuk melakukan premature sign off. Penelitian Liantih (2010); Lestari (2010); Qurrahman, et al. (2012); Budiman (2013); Priyanto (2014); dan Haryanto (2015) menunjukkan bahwa prosedur review dan kontrol kualitas berpengaruh negatif terhadap premature sign-off. Semakin baik prosedur review dan kontrol kualitas, semakin rendah kemungkinan auditor untuk melakukan premature sign off.

Penelitian tersebut menjelaskan bahwa semakin kecil kemungkinan praktik penghentian prematur atas prosedur audit jika prosedur review dan kontrol kualitas telah diterapkan dengan efektif, begitu pula sebaliknya. Prosedur review yaitu berupa peninjauan kembali apakah auditor telah berhasil atau gagal menyelesaikan seluruh prosedur audit dan bukti pelengkap yang dibutuhkan telah lengkap, sehingga dapat diketahui apakah auditor benar-benar telah melaksanakan seluruh prosedur audit atau menghilangkan prosedur tertentu. Kontrol kualitas bertujuan untuk memastikan apakah jasa yang diberikan auditor berkualitas. Kualitas tersebut ditentukan berdasarkan kesesuaian prosedur audit yang dijalankan auditor dengan standar seperti kebijakan KAP dan standar profesional auditor. Berdasarkan uraian di atas, maka hipotesis kelima dirumuskan sebagai berikut:

\section{$\boldsymbol{H}_{\mathbf{5}}$ : Prosedur review dan kontrol kualitas berpengaruh negatif terhadap penghentian prematur atas prosedur audit.}

\section{Pengaruh External Locus Of Control terhadap Perilaku Premature Sign-Off}

Lestari (2010) menyatakan bahwa perilaku penghentian prematur atas prosedur audit cenderung akan terjadi pada individu yang memiliki locus of control eksternal karena auditor dengan external locus of control akan melakukan segala cara untuk mencapai tujuannya. Teori atribusi merupakan salah satu teori yang dapat menentukan apakah auditor tersebut memiliki locus of control internal atau eksternal (Heider, 1958). Teori atribusi merupakan salah satu teori yang menjelaskan hubungan karakteristik auditor terhadap perilaku prematur sign off. Teori atribusi membagi karakter individu menjadi dua yaitu individu "Y" sebagai internal locus of control dan individu " $\mathrm{X}$ " sebagai external locus of control.

Penelitian Liantih (2010); Qurrahman, et al. (2012); Budiman (2013); Asrini, et al. (2014); Haryanto (2015) dan Junaidi (2016) menunjukkan bahwa external locus of control berpengaruh positif terhadap penghentian prematur atas prosedur audit. Penelitian sebelumnya menunjukkan bahwa semakin kuat external locus of control seorang auditor, semakin besar kemungkinan timbulnya perilaku premature sign off oleh auditor.

Penelitian di atas menjelaskan jika perbedaan karakter auditor dapat terlihat seperti dalam kondisi time pressure dimana auditor merasa tidak yakin untuk menyelesaikan tugas auditnya sesuai waktu dalam perjanjian. Ketika waktu audit semakin sedikit sedangkan terdapat bebrapa prosedur yang belum dilaksanakan, maka sifat auditor dengan locus of control eksternal yang mudah menyerah dan tidak suka berusaha dapat menuntutnya untuk meninggalkan prosedur tertentu yang dianggap tidak penting sebagai bentuk pengorbanan agar dapat selesai tepat pada waktunya. Sifat auditor dengan locus of control internal yang tidak mudah menyerah dan ingin burusaha akan membuat auditor bersedia berusaha menyelesaikan seluruh prosedur sesuai standar untuk menghindari kesalahan dalam pemberian opini audit. Berdasarkan uraian di atas, maka hipotesis keenam dirumuskan sebagai berikut: 


\section{$\boldsymbol{H}_{6}$ : External locus of control berpengaruh positif terhadap penghentian prematur atas prosedur audit.}

\section{Pengaruh Komitmen Organisasi terhadap Perilaku Premature Sign-Off}

Auditor yang berkomitmen, akan selalu berusaha untuk mempertahankan keanggotaannya dalam organisasi (Nasution, 2013). Komitmen ini dapat terlihat dari kesetiaan pegawai terhadap organisasi, keinginan untuk melaksanakan pekerjaan tambahan, serta perputaran pegawai (Sampetoding, 2014). Penelitian Widyowati (2013) dan Sampetoding (2014) menunjukkan bahwa komitmen organisasi berpengaruh negatif terhadap premature sign-off. Pernyataan tersebut menunjukkan bahwa semakin tinggi komitmen organisasi seorang auditor maka semakin rendah kemungkinan premature sign off oleh auditor, karena auditor akan mengesampingkan egonya untuk mecapai tujuan pribadi demi memenuhi kepentingan organisasi. Penelitian di atas menjelaskan bahwa seorang auditor yang memiliki komitmen organisasi berarti berjanji kepada KAP untuk bekerja sesuai tujuan, nilai, kebijakan dan standar audit sehingga ia tidak akan melakukan penyimpangan seperti menghentikan prosedur audit secara prematur.

Komitmen auditor terhadap organisasi tercermin ketika auditor dapat menyelesaikan seluruh prosedur audit sesuai standar yang berlaku serta memberikan opini secara tepat dan objektif sesuai hasil audit yang sebenarnya. Sebaliknya, auditor dengan komitmen organiasi yang rendah tidak memiliki motivasi untuk bekerja sungguh-sungguh, sehingga semakin besar kemungkinan untuk melakukan penyimpangan seperti prematur sign-off. Berdasarkan uraian di atas, maka hipotesis ketujuh dirumuskan sebagai berikut:

\section{$\boldsymbol{H}_{7}$ : Komitmen organisasi berpengaruh negatif terhadap penghentian prematur atas prosedur audit.}

\section{Pengaruh Turnover Intention terhadap Perilaku Premature Sign-Off}

Pada umumnya, turnover intention berawal dengan adanya konflik baik antara auditor dengan klien atau auditor dengan auditor lainnya atau auditor dengan dirinya sendiri (Pujaningrum \& Sabeni, 2012). Auditor yang memiliki keinginan untuk berhenti bekerja cenderung kurang peduli terhadap apa yang dilakukannya selama masih berada di KAP tersebut. Auditor dengan turnover intention yang tinggi, memiliki kecenderungan yang lebih besar untuk melakukan disfungsional audit karena menurunnya rasa takut akan terkena sanksi atas perbuatannya tersebut (Harini, Wahyudin, \& Anisykurlillah, 2010).

Penelitian yang dilakukan oleh Wijayanti (2007); Pujaningrum dan Sabeni (2012) menunjukkan bahwa turnover intention berpengaruh positif terhadap premature sign-off. Hal tersebut membuktikan bahwa semakin tinggi turnover intention auditor semakin tinggi kemungkinan auditor untuk melakukan premature sign-off. Penelitian tersebut, menjelaskan bahwa auditor yang berniat untuk segara mendapatkan pekerjaan lain yang dirasa lebih baik untuk dirinya akan cenderung dapat melakukan penyimpangan seperti premature sign off. Hal ini karena penurunan kepedulian terhadap dampak buruk terhadap posisinya seperti pemecatan apabila perbuatannya diketahui. Berdasarkan uraian di atas, maka hipotesis kedelapan dirumuskan sebagai berikut:

\footnotetext{
$\boldsymbol{H}_{\mathbf{8}}$ : Turnover intention berpengaruh positif terhadap penghentian prematur atas prosedur audit.
} 


\section{METODE PENELITIAN}

Populasi dalam penelitian ini adalah seluruh auditor yang bekerja pada Kantor Akuntan Publik (KAP) yang terdaftar pada OJK. Sampel dari penelitian ini yaitu auditor yang bekerja di Kantor Akuntan Publik wilayah Yogyakarta dan Semarang berdasarkan data OJK (www.OJK.co.id) bulan maret 2017 yang merupakan update terakhir dari OJK. Jenis data yang digunakan dalam penelitian ini adalah data primer. Teknik pengambilan sampel pada penelitian ini menggunakan metode purposive sampling. Kriteria sampel penelitian ini adalah auditor yang bekerja pada Kantor Akuntan Publik di Yogyakarta dan Semarang yang terdaftar pada OJK (Otorisasi Jasa Keuangan) tahun 2017 dan telah bekerja minimal 1 tahun. Teknik pengumpulan data dilakukan dengan kuesioner. Hipotesis dalam penelitian ini diuji dengan menggunakan uji Friedman (Hipotesis 1) dan uji regresi linear berganda (Hipotesis 2-8).

\section{Variabel Independen Variabel Dependen}

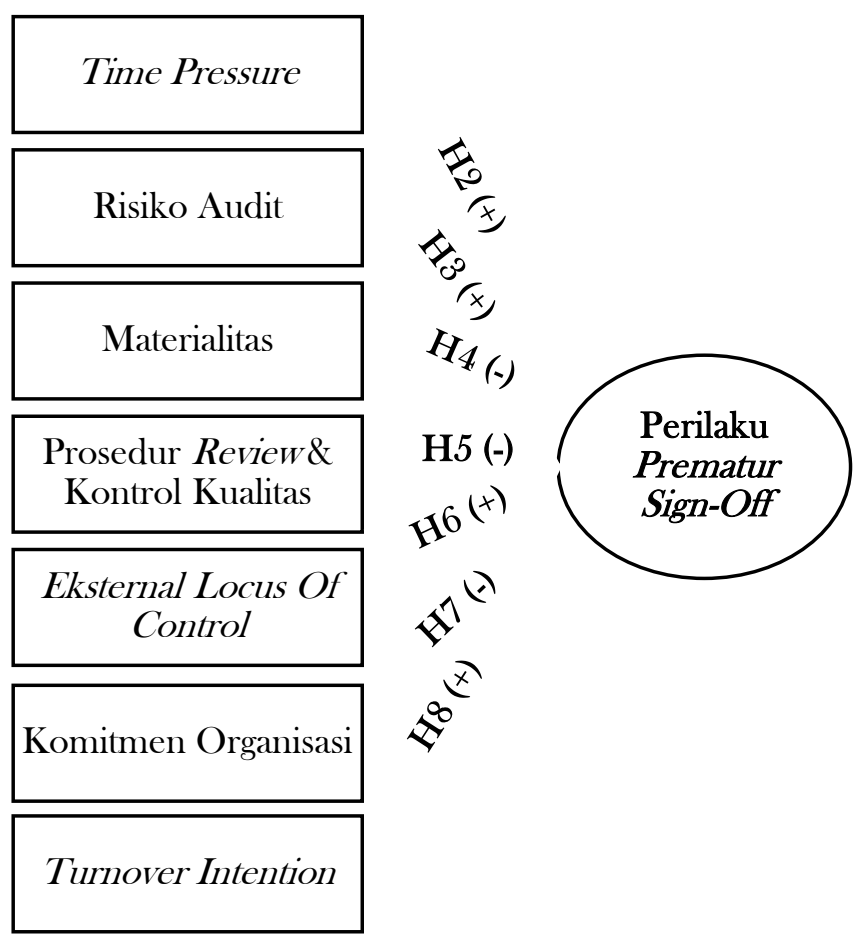

Gambar 1

Model Penelitian

\section{HASIL DAN PEMBAHASAN}

Statistik deskriptif demografi responden menunjukkan bahwa penelitian ini didominasi oleh responden wanita sebanyak 29 auditor, responden berusia < 31 tahun sebanyak 40 auditor, responden dengan pendidikan terkahir S1 sebanyak 42 auditor, responden dengan lama kerja 1-5 tahun sebanyak 38 auditor dan responden dengan jabatan junior auditor sebanyak 29 auditor. Proses analisis data yang dilakukan meliputi proses sampling, statistik deskriptif pengujian kualitas instrumen dan data, pengujian asumsi klasik dan pengujian hipotesis.

Uji Friedman (Hipotesis 1) 
Uji Friedman bertujuan untuk menguji apakah ada perbedaan dalam urutan prioritas prosedur audit yang dihentikan secara prematur oleh auditor. Hasil pengujian dengan statistik non parametrik Friedman diperoleh hasil sebagai berikut:

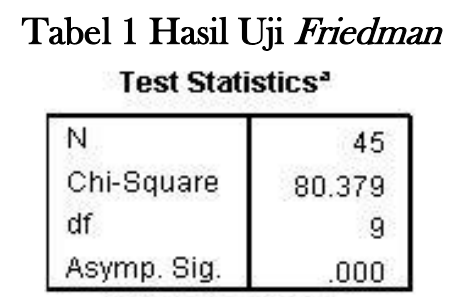

a. Friedman Test

Sumber: Data primer yang diolah, 2017

Nilai Asymp. Sig. diperoleh sebesar 0,000 < alpha (5\%). Hal tersebut menunjukkan bahwa Hipotesis $1\left(\boldsymbol{H}_{\mathbf{1}}\right)$ diterima, dimana terdapat perbedaan urutan prioritas prosedur audit yang dihentikan secara prematur. Sebagain besar responden mengaku pernah menghentikan beberapa prosedur karena situasi tertentu seperti ketika berada pada tekanan untuk menyelesaikan audit sesuai anggaran waktu. Berikut ini adalah urutan prioritas prosedur audit yang dihentikan berdasarkan hasil uji Friedman:

Tabel 2 Urutan Prioritas Prosedur Audit

\begin{tabular}{lc}
\hline \multicolumn{1}{c}{ Prosedur analitis } & Prioritas \\
\hline Pemahaman bisnis klien & 5 \\
Pertimbangan pengendalian intern klien & 4 \\
Menggunakan informasi asersi & 2 \\
Pertimbangan internal auditor & 3 \\
Prosedur analitis & 8 \\
Konfirmasi & 9 \\
Menggunakan representasi manajemen & 6 \\
Melaksanakan uji kepatuhan terhadap pengendalian atas transaksi dalam & 1 \\
aplikasi sistem online & \\
Mengurangi jumlah sampel & 7 \\
Pemeriksaan fisik & 10 \\
\hline
\end{tabular}

Sumber: Data primer yang diolah, 2017

Tabel 2 menunjukkan bahwa prioritas pertama prosedur audit yang sering dilakukan penghentian prematur yaitu prosedur melaksanakan uji kepatuhan terhadap pengendalian atas transaksi dalam aplikasi sistem online. Hal tersebut karena jejak audit saat melaksanakan prosedur tersebut tidak terlihat sehingga penyimpangan tidak mudah terdeteksi. Prioritas terakhir atau ke 10 yang paling jarang dilakukan penghentian prematur adalah pemeriksaan fisik. Prosedur tersebut dianggap paling penting karena bagian persediaan sangatlah rawan terhadap penyimpangan sehingga pemeriksaan fisik menjadi salah satu prosedur yang paling penting dalam mendeteksi penyimpangan tersebut. Contoh kasus penyimpangan terkait persediaan adalah fraud PT. Kimia Farma tahun 2002 yaitu penggelembungan persediaan.

Uji Regresi Linear Berganda (Hipotesis 2-8)

Uji Koefisien Determinasi (Adjusted $\boldsymbol{R}^{2}$ ) 
Berdasarkan hasil uji Koefisien Determinasi (Adjusted $R^{2}$ ) pada tabel Model Summary ${ }^{b}$, nilai Adjusted $R$ Square adalah 0,602. Hal tersebut berarti bahwa variabel independen dapat menjelaskan variabel dependen sebesar 60,2\%, sedangkan 39,8\% dijelaskan oleh faktor lain yang tidak terdapat dalam model ini.

\section{Uji Simultan (Uji Nilai $F$ )}

Berdasarkan hasil uji simultan pada tabel $A_{n o v}{ }^{b}$, nilai sig adalah 0,000 <0,05 (alpha) atau $5 \%$. Hal tersebut menunjukkan bahwa ke tujuh variabel independen memiiki pengaruh bersamasama terhadap perilaku penghentian prematur atas prosedur audit.

\section{Uji Parsial (Uji Nilai $t)$}

\section{Tabel 3 Hasil Uji Parsial (Uji Nilai $t$ ) Coefficients ${ }^{a}$}

\begin{tabular}{|c|r|r|r|}
\hline \multirow{2}{*}{ Model } & \multicolumn{2}{|c|}{$\begin{array}{c}\text { Un standardized } \\
\text { Coefficients }\end{array}$} & \multirow{2}{*}{ Sig. } \\
\cline { 2 - 3 } & \multicolumn{1}{|c|}{ B } & Std. Error & \\
\hline 1 Constant) & 5,099 & 16,288 & 0,756 \\
\hline TP & $\mathbf{0 , 9 7 0}$ & $\mathbf{0 , 2 8 3}$ & $\mathbf{0 , 0 0 2}$ \\
\hline RA & $-0,318$ & 0,485 & 0,517 \\
\hline M & $-0,280$ & 0,551 & 0,615 \\
\hline PR & $-0,399$ & 0,528 & 0,455 \\
\hline L & $\mathbf{0 , 8 6 7}$ & $\mathbf{0 , 3 1 2}$ & $\mathbf{0 , 0 0 9}$ \\
\hline KO & $-0,187$ & 0,197 & 0,349 \\
\hline TI & 0,669 & 0,383 & 0,089 \\
\hline
\end{tabular}

Dependent variable: PSO

Sumber: Data primer yang diolah, 2017

Berdasarkan pada tabel 3 maka diperoleh rumus persamaan regresi linear berganda sebagai berikut:

PSOi $=5,099+0,970 \mathrm{TP}-0,318 \mathrm{RA}-0,280 \mathrm{M}-0,399 \mathrm{PR}+0,867 \mathrm{~L}-0,187 \mathrm{KO}+0,669 \mathrm{TI}+\mathrm{e}$

Pengujian hipotesis kedua $\left(\boldsymbol{H}_{2}\right)$ pada tabel 4.25 mengenai pengaruh time pressure terhadap penghentian prematur atas prosedur audit menunjukkan bahwa nilai koefisien regresi sebesar 0,970 dengan signifikansi sebesar $0,002<$ alpha 0,05 . Artinya time pressure memiliki pengaruh positif terhadap perilaku penghentian prematur atas prosedur audit. Oleh karena itu dapat disimpulkan bahwa Hipotesis kedua $\left(\boldsymbol{H}_{2}\right)$ diterima.

Sebagian besar akuntan merasa bahwa anggaran waktu yang diberikan seringkali tidak wajar, akan tetapi tuntutan untuk bekerja secara profesional mengharuskan auditor untuk mencapai waktu yang telah ditetapkan sesuai perjanjian (Basuki \& Mahardani, 2006). Berdasarkan jawaban responden terhadap pertanyaan dalam kuesioner yang berkaitan dengan time pressure, Sebagian besar responden sering merasa jika anggaran waktu dalam melakukan audit kurang. Sebagain responden juga menyetujui pernyataan, jika mereka sering mengaudit beberapa perusahaan dalam periode bersamaan, bahkan mereka sering lembur dalam mengaudit.

Semakin singkat waktu yang ditetapkan dalam mengaudit artinya semakin tinggi tekanan waktu, maka semakin besar kemungkinan auditor untuk tidak menguji beberapa transaksi. Rasa khawatir tidak dapat menyelesaikan seluruh prosedur sesuai anggaran waktu, dapat menyebabkan auditor memilih untuk meninggalkan satu atau beberapa prosedur yang dirasa tidak cukup penting dalam pengambilan opini audit.

Pengujian hipotesis ketiga $\left(\boldsymbol{H}_{\mathbf{3}}\right)$ pada tabel 3 mengenai pengaruh risiko audit terhadap penghentian prematur atas prosedur audit menunjukkan nilai koefisien regresi sebesar- 0,318 dengan signifikansi sebesar $0,517>$ alpha 0,05 . Berarti risiko audit tidakmemiliki pengaruh terhadap perilaku penghentian prematur atas prosedur audit. Oleh karena itu dapat disimpulkan bahwa Hipotesis ketiga $\left(\boldsymbol{H}_{3}\right)$ ditolak. 
Pertimbangan tinggi rendahnya risiko audit bersifat estimasi atau perkiraan yang melibatkan kemampuan masing-masing auditor dalam menilai risiko audit. Kemampuan setiap auditor yang berbeda-beda menyebabkan hasil perkiraan risiko juga berbeda-beda. Keyakinan yang tinggi akan kemampuan auditor bahwa ia mampu menyusun opini yang tepat membuat auditor tidak takut terhadap resiko yang mungkin terjadi jika ia menghentikan prosedur tertentu.

Pengujian hipotesis keempat $\left(\boldsymbol{H}_{\mathbf{4}}\right)$ pada tabel 3 mengenai pengaruh materialitasterhadap penghentian prematur atas prosedur audit menunjukkan nilai koefisien regresi sebesar- 0,280 dengan signifikansi sebesar $0,615>$ alpha 0,05 . Berarti materialitas tidakmemiliki pengaruh terhadap perilaku penghentian prematur atas prosedur audit, sehingga dapat disimpulkan bahwa Hipotesis keempat $\left(\boldsymbol{H}_{4}\right)$ ditolak.

Hal ini karena materialitas merupakan hal yang melekat pada laporan keuangan, sehingga materialitas tidak akan mempengaruhi proses pelaksanaan prosedur audit. Auditor eksternal sebagai penyedia jasa atestasi tidak dapat memberikan kepastiankepada pengguna laporan keuanganatas keakuratan laporan keuangan yang telah diaudit. Auditor hanya dapat memberikan keyakinan melalui tingkat materialitas yang di asumsikan. Selain itu, pertimbangan materialitas telah dilakukan pada saat perancangan prosedur pemilihan dan pemeriksaan sampel, sehingga prosedur audit yang dilaksanakan telah sesuai dengan sampel yang direncanakan di awal.

Pengujian hipotesis kelima $\left(\boldsymbol{H}_{\mathbf{5}}\right)$ pada tabel 3 mengenai pengaruh prosedur review dan kontrol kualitasterhadap penghentian prematur atas prosedur audit menunjukkan nilai koefisien regresisebesar- 0,399 dengan signifikansi sebesar 0,455 > alpha 0,05. Berarti prosedur review dan kontrol kualitas tidakmemiliki pengaruh terhadap perilaku penghentian prematur atas prosedur audit, sehingga dapat disimpulkan bahwa Hipotesis kelima $\left(\boldsymbol{H}_{5}\right)$ ditolak.

Berdasarkan jawaban responden, sebagai besar responden merasa bahwa prosedur review dan kontrol kualitas di KAP tempat ia bekerja masih belum efektif, sehingga fungsinya tidak berjalan sebagaimana mestinya, khususnya untuk mencegah maupun mengungkap penyimpangan dalam proses audit. Selain itu, keyakinan bahwa tanpa melakukan prosedur tertentu auditor tetap akan mampu menghasilkan hasil audit yang berkualitas dapat menjadi salah satu alasan auditor tetap melakukan penyimpangan tersebut, sehingga ia tidak takut terhadap prosedur review dan kontrol kualitas yang berlaku.

Pengujian hipotesis keenam $\left(\boldsymbol{H}_{\mathbf{6}}\right)$ pada tabel 3 mengenai pengaruh externallocus of control terhadap penghentian prematur atas prosedur audit menunjukkan nilai koefisien regresi sebesar0,867 dengan signifikansi sebesar 0,009 < alpha 0,05. Berarti externallocus of control memiliki pengaruh positif terhadap perilaku penghentian prematur atas prosedur audit. Oleh karena itu dapat disimpulkan bahwa Hipotesis keenam $\left(\boldsymbol{H}_{\mathbf{6}}\right)$ diterima.

Berdasarkan teori atribusi, sifat auditor dengan locus of control eksternal disebut sebagai individu x. Individu x yang mudah menyerah dan tidak suka berusaha memiliki potensi lebih besar untuk melakukan penghentian prematur atas prosedur audit tertentu yang dianggap tidak penting sebagai cara untuk bertahan dalam lingkungan pekerjaannya. Hal ini dapat terjadi seperti dalam kondisi time pressure dimana auditor tidak merasa yakin untuk menyelesaikan tugas auditnya sesuai waktu dalam perjanjian, sehingga ia dapat melakukan segala cara untuk menyelesaikan tugasnya seperti penghentian prematur atas prosedur audit.

Berdasarkan jawaban responden, sebagai besar auditor percaya bahwa untuk mendapatkan pekerjaan yang baik itu tergantung nasib dan juga koneksi. Hal itu merupakan salah satu ciri dari auditor dengan external locus of control, sehingga terbukti bahwa sebagain besar responden memiliki locus of control eksternal.

Pengujian hipotesis keempat $\left(\boldsymbol{H}_{\mathbf{7}}\right)$ pada tabel 3 mengenai pengaruh komitmen organisasiterhadap penghentian prematur atas prosedur audit menunjukkan nilai koefisien regresi sebesar- 0,187 dengan signifikansi sebesar $0,349>$ alpha 0,05. Berarti komitmen organisasitidakmemiliki pengaruh terhadap perilaku penghentian prematur atas prosedur audit, sehingga dapat disimpulkan bahwa Hipotesis ketujuh $\left(\boldsymbol{H}_{\mathbf{7}}\right)$ ditolak.

$65 \%$ responden merupakan auditor junior, $89 \%$ responden berusia kurang dari 31 tahun dan 84\% responden memiliki masa kerja 1 hingga 5 tahun. Para auditor junior muda, cenderung berfokus untuk karir dan berkomitmen untuk bekerja dengan baik saja. Kenaikan jabatan atau 
pekerjaaan yang lebih baik merupakan salah satu tujuan utama atas hasil kerjanya yang baik, bukan karena semata-mata berkomitmen terhadap organisasi atau KAP tempat ia bekerja. Walaupun responden memiliki komitmen organisasi, akan tetapi keinginan untuk naik jabatan dan rasa takut terhadap resiko khususnya pemecatan merupakan salah satu motivasi utama auditor untuk tidak melakukan penyimpangan seperti penghentian prematur atas prosedur audit. Sehingga dapat disimpulkan bahwa komitmen organisasi tidak berpengaruh terhadap perilaku penghentian prematur atas prosedur audit.

Pengujian hipotesis kedelapan $\left(\boldsymbol{H}_{\mathbf{8}}\right)$ pada tabel 2 mengenai pengaruh turnover intention terhadap penghentian prematur atas prosedur audit menunjukkan nilai koefisien regresisebesar 0,669 dengan signifikansi sebesar 0,089 > alpha 0,05. Berarti turnover intention tidakmemiliki pengaruh terhadap perilaku penghentian prematur atas prosedur audit, sehingga dapat disimpulkan bahwa Hipotesis kedelapan $\left(\boldsymbol{H}_{\mathbf{8}}\right)$ ditolak.

65\% responden adalah auditor junior, 89\% responden berusia kurang dari 31 tahun, 93\% responden memiliki pendidikan akhir S1, 84\% responden memiliki masa kerja 1 hingga 5 tahun. Tingkat indealisme yang tinggi terhadap pekerjaan pada diri auditor junior yang belum lama lulus S1, menjadi salah satu alasan mereka untuk tidak melakukan penyimpangan seperti penghentian prematur atas prosedur audit. Auditor junior cenderung akan melaksanakan tanggung jawabnya dengan sebaik mungkin sesuai dengan prosedur, aturan atau kebijakan yang berlaku. Mereka tidak memliki rencana untuk meninggalkan pekerjaannya pada KAP tersebut melihat persaingan yang ketat dalam lingkungan kerja saat ini. Hal tersebut terbukti dengan persetujuan para responden terkait pernyataan bahwa mereka tidak akan meninggalkan pekerjaannya saat ini dalam waktu 2 hingga 5 tahun kedepan.

\section{KETERBATASAN PENELITIAN}

Penelitian ini memiliki beberapa keterbatasan yang dapat disempurnakan oleh penelitian selanjutnya. Keterbatasan penelitian ini yaitu sampel dalam penelitian ini hanya sedikit yaitu para auditor yang bekerja pada KAP di wilayah Yogyakarta dan Semarang. Waktu penyebaran kuesioner yang mendekati akhir tahun juga menyebabkan jumlah sampel hanya sedikit dikarenakan banyak auditor yang sedang bertugas mengaudit di lapangan. Variabel independen yaitu faktor internal dan eksternal auditor yang dianalisis dalam penelitian ini berjumlah 7 variabel yaitu 4 faktor eksternal auditor dan 3 faktor internal auditor, keterbatasan faktor khususnya faktor internal auditor yang masih sedikit di teliti.

Keterbatasan lainnya yaitu penelitian ini menggunakan metode pengumpulan data melalui penyebaran kuesioner secara langsung yang membutuhkan waktu cukup lama dari waktu penyebaran hingga pengambilan. Metode kuesioner juga dapat menghasilkan jawaban yang bias dari responden, karena ketidakseriusan responden dalam menjawab pertanyaan.

\section{KESIMPULAN}

Berdasarkan hasil analisis SPSS terhadap data jawaban responden pada auditor di KAP Yogyakarta dan Semarang, maka dapat ditarik kesimpulan bahwa terdapat perbedaan urutan prioritas dari prosedur audit yang dihentikan secara prematur. Berdasarkan uji Friedman prosedur yang paling sering dihentikan oleh auditor yaitu uji kepatuhan terhadap pengendalian atas transaksi dalam aplikasi sistem online, sedangkan prosedur yang paling jarang dihentikan yaitu pemeriksaan fisik seperti. Time pressure berpengaruh positif terhadap perilaku penghentian prematur atas prosedur audit. Resiko audit tidak berpengaruh terhadap perilaku penghentian prematur atas prosedur audit.

Materialitas tidak berpengaruh terhadap penghentian prematur atas prosedur audit. Prosedur review dan kontrol kualitas tidak berpengaruh terhadap perilaku penghentian prematur atas prosedur audit. External locus of control berpengaruh positif terhadap perilaku penghentian 
prematur atas prosedur audit. Komitmen organisasi tidak berpengaruh terhadap perilaku penghentian prematur atas prosedur audit. Turnover intention tidak berpengaruh terhadap perilaku penghentian prematur atas prosedur audit.

Berdasarkan hasil penelitian yang telah dilakukan, terdapat beberapa saran-saran yang dapat peneliti berikan bagi penelitian selanjutnya, yaitu penelitian selanjutnya sebaiknya memperluas wilayah sampel penelitian seperti sampel pada provinsi tertentu sehingga sampel lebih banyak. Penelitian selanjutnya sebaiknya menambah jumlah variabel independen khususnya faktor internal auditor seperti agama, gender, komitmen profesional, pengalaman auditor, harga diri yang kaitannya dengan ambisi, etika auditor, persepsi tingkat kinerja pribadi, Equity sensitivity dan lainnya. Faktor eksternal auditor yang lain seperti fee audit, tekanan klien dan lainnya.

Penelitian selanjutnya dapat menggunakan metode wawancara secara langsung kepada responden agar jawaban yang diberikan tidak bersifat bias. Penelitian selanjutnya agar tetap menggunakan metode penyebaran secara langsung dan lebih memperhatikan waktu penelitian yang tepat mulai waktu penyebaran hingga pengambilan kuesioner sekitar di awal hingga pertengahan tahun.

\section{DAFTAR PUSTAKA}

Al-Qur'an Surat. Al-Ahzab (33): ayat 72

Alderman, C.W., \& Deitrick, J.W. (1982). Auditor's Perceptions of Time Budget Pressure and Premature Sign-0ffs: A Replication and Extension. Auditing: A Journal of Practice and Theory. 1(2), 54-58.

Andani, N. M. S., \& Mertha, I. M. (2014). Pengaruh Time Pressure, Audit Risk, Professional Commitment dan Locus of Control pada Penghentian Prematur Prosedur Audit. E-Jurnal Akuntansi Universitas Udayana, 2(6,2), 185-196.

Asrini, K. J., Sujana, E., \& Darmawan, N. A. S. (2014). Pengaruh Tekanan Waktu, Locus of Control dan Tindakan Supervisi terhadap Penghentian Prematur atas Prosedur Audit: Studi Empiris pada Kantor Akuntan Publik di Bali. Skripsi, Universitas Pendidikan Ganesha, 2(1).

Basuki \& Mahardani, K. Y. (2006). Pengaruh Tekanan Anggaran Waktu terhadap Perilaku Disfungsional Auditor dan Kualitas Audit pada Kantor Akuntan Publik di Surabaya. Jurnal Maksi, Vol. 6, No. 2, 203-221.

Budiman, N. A. (2013). Pengaruh Faktor Internal Dan Eksternal Auditor Terhadap Penghentian Prematur Atas Prosedur Dan Kualitas Audit. Jurnal Akuntansi Dan Manajemen, 24(3), 131142.

Dewan Perwakilan Rakyat Republik Indonesia dan Presiden Republik Indonesia. 2011. Undangundang Republik Indonesia Nomor 5 Tahun 2011 Tentang Akuntan Publik

Dewan Perwakilan Rakyat Republik Indonesia dan Presiden Republik Indonesia. (2004). UndangUndang Republik Indonesia Nomor 1 Tahun 2004 Tentang Perbendaharaan Negara. D.Hendianto-Biro Hukum BPK-RI/10/16/2006.

Dewan Standar Akuntansi Keuangan Ikatan Akuntansi Indonesia. (2004). Exposure Draft PSAK No. 24 (Revisi 2004).

Dewan Standar Akuntansi Keuangan Ikatan Akuntansi Indonesia. (2009). Pernyataan Standar Akuntansi Keuangan 1 (revisi 2009) tentang Penyajian Laporan Keuangan.

Dharmasaputra, M. (2017). Indeks Persepsi Korupsi Indonesia Peringkat 4 di ASEAN. Retrieved May 27, 2017, from http://bit.ly/2jQaDnC, Diakses tanggal 27 Mei 2017.

Fakrullah, Z. A. (2011). Akuntabilitas Kebijakan dan Pembudayaan Perilaku Antikorupsi. Prespektif, 16(2), 105-116.

Harini, D., Wahyudin, A., \& Anisykurlillah, I. (2010). Analisis Penerimaan Auditor Atas Dysfunctional Audit Behavior: Sebuah Pendekatan Karakteristik Personal Auditor. Simposium Nasional Akuntansi XIII Purwokerto, 13, 1-28.

Haryanto, S. M. (2015). Faktor eksternal dan internal yang memengaruhi auditor dalam penghentian prematur atas prosedur audit. Skripsi, Universitas Hasanuddin Makassar. 
Heider, F. (1958). The psychology of interpersonal relations. New York: Wiley.

Herningsih, S. (2001). Penghentian Prematur Atas Prosedur audit : Studi Empiris pada Kantor Akuntan Publik. Tesis, Universitas Gajah Mada Yogyakarta.

Heriningsih, S. (2002). "Penghentian Prematur Atas Prosedur Audit: Sebuah Studi Empiris Pada Kantor Akuntan Publik”. Wahana, 2, 111-122.

Ikatan Akuntansi Indonesia. (2001). Standar Profesional Akuntan Publik Per 1 Januari 2001. Jakarta : Salemba Empat.

Ismoyo, B. (2017). Indeks Persepsi Korupsi Indonesia Disebut "Membaik" tapi Lamban. Retrieved May 27, 2017, from http://bit.ly/2si3XW4, Diakses tanggal 27 Mei 2017.

Junaidi, A. T. (2016). Pengaruh Tekanan Waktu, Locus of Control, Tindakan Supervisi dan Materialitas terhadap Penghentian Prematur atas Prosedur Audit : Studi Empiris pada Kantor Akuntan Publik Di Surakarata dan Semarang). Skripsi, Universitas Muhammadiyah Surakarta.

Koesman, A. (2011). Peran akuntan Dalam pemberantasan korupsi dan Peningkatan transparan sektor publik. Jurnal PWI Tebing Tinggi.

Lestari, A. P. (2010). Faktor-faktor yang Mempengaruhi Perilaku Auditor dalam Penghentian Prematur Prosedur Audit. Skripsi Universitas Diponegoro.

Liantih, R. (2010). Analisis Faktor-faktor yang Mempengaruhi Penghentian Prosedur atas Prosedur Audit. Skripsi, Universitas Diponegoro.

McGregor, D. (1960). The Personal Management. New York: McGraw-Hill.

Messier, W. F. (2000). Auditing and Assurance Services: A Systematic Approach. United States of America:McGraw-Hill Companies

Mulyadi. (2010). Auditing, Buku 1 (6th ed.). Jakarta: Salemba Empat.

Nasution, I. (2013). Pengaruh Karateristik Personal Auditor , Etika Audit dan Pengalaman Auditor Terhadap Tingkat Penyimpangan Perilaku dalam Audit. Skripsi, Universitas Islam Negeri Syarif Hidayatullah.

Nisa, V. F. (2013). Internal yang Mempengaruhi Penghentian Prematur atas Prosedur Audit : Studi Empiris pada Kap Di Semarang. Skripsi, Universitas Diponegoro.

Otoritas Jasa Keuangan. (2017). Daftar Kantor Akuntan Publik / Akuntan Publik yang Terdaftar Sebagai Auditor Bank di Otoritas Jasa Keuangan 1 Maret 2017, 1-6.

Priyanto. (2014). Faktor-faktor yang Mempengaruhi Penghentian Prematur Prosedur Audit. Skripsi Unika Soegijapranata, 10(2), 116-127.

Pujaningrum, I., \& Sabeni, A. (2012). Analisis Faktor-Faktor yang Mempengaruhi Tingkat Penerimaan Auditor atas Penyimpangan Perilaku dalam Audit : Studi Empiris pada Kantor Akuntan Publik di Semarang. DiponegoroJournal Of Accounting, 1(2), 1-15.

Putra, L. M. (2017). Indeks Persepsi Korupsi Indonesia Naik Satu Poin. Retrieved May 27, 2017, from http://bit.ly/2rNgfCl, Diakses tanggal 27 Mei 2017.

Putriana, A., Respati, N. W., \& Chairina. (2015). Faktor-Faktor yang Mempengaruhi Perilaku Auditor dalam Penghentian Prematur Prosedur Audit. Jurnal Akuntansi \& Investasi, 10(18196), 121-131. https://doi.org/10.18196/JAI-2015.0037

Qurrahman, T., Susfayetti, \& Mirandah, A. (2012). Pengaruh Time Presure, Resiko Audit, Materialitas, Prosedur Review dan Kontrol Kualitas, Locus Of Control Serta Komitmen Profesional Terhadap Penghentian Prematur Prosedur Audit (Studi Empiris Pada KAP Di Palembang). Jurnal Binar Akuntansi, 1(1).

Raghunathan, B. (1991). Premature Signing-Off of Audit procedures: An Analysis. Accounting Horizons. 5(2), 71-79.

Rochman, M.N., Andini, R., Oemar, A. (2016). Pengaruh Time Pressure, Resiko Audit, Materialitas, Prosedur Review dan Kontrol Kualitas, Locus of Control, Komitmen Profesional terhadap Penghentian Prematur atas Prosedur Audit: Studi Empiris Pada KAP Semarang. Journal Of Accounting, (2), 2.

Sampetoding, P. R. (2014). Hubungan antara Time Budget Pressure, Locus of Control dan Komitmen Organisasi terhadap Perilaku Disfungsional Audit dan Pengaruhnya pada Kualitas Audit : Survey pada Auditor Perwakilan BPKP Provinsi Sulawesi Selatan. Skripsi, 
Universitas Hasanuddin Makassar.

Suartana, I. W. (2010). Akuntansi Keperilakuan. (W. Vidya, Ed.) (1st ed.). Yogyakarta: Andi Offset.

Sunyoto, Y. C. S. (2014). Pengaruh Karakteristik Personal Auditor Terhadap Penerimaan Perilaku Penghentian Prematur (Studi Pada Kantor Akuntan Publik Kota Surakarta dan Yogyakarta). Skripsi, Universitas Muhammadiyah Surakarta.

Waggoner, J. B. \& Cashell, J. D. (1991). The Impact of Time Pressure on Auditors Performance. The Ohio CPA Journal.

Wahyudi, I., Lucyanda, J., \& Suhud, L. H. (2011). Praktik Penghentian Prematur atas Prosedur Audit. Media Riset Akuntansi, 1(2).

Wibowo, K. P., \& Mu'id, D. (2008). Profesionalisme Auditor dalam Penghentian Prematur atas Prosedur Audit : Studi Empiris Pada KAP Di Semarang. Skripsi Universitas Diponegoro.

Widyowati, M. P. (2013). Analisis Pengaruh Karakteristik Internal Pada Auditor Eksternal Terhadap Praktik Pengurangan Kualitas Audit. Skripsi Universitas Jember.

Wijayanti, P. (2007). Pengaruh Karakteristik Personal Audito terhadap Penerimaan Perilaku Disfungsional Audit : Studi Empiris pada Auditor Pemerintah Yang bekerja di BPKP Di Jawa Tengah dan DI Yogyakarta. Tesis, Universitas Diponegoro. 